\title{
IMPACT OF SHADOW BANKING ACTIVITIES AS NON BANK INTERMEDIATION TOWARD REGULATORY DEVELOPMENTS IN FUNCTION CONTROL OF FINANCIAL SERVICES SECTOR IN INDONESIA
}

\author{
Lastuti Abubakar*) C. Sukmadilaga, Tri Handayani \\ Faculty of Law Padjajaran University Bandung \\ lastuti.abubakar@unpad.ac.id
}

\begin{abstract}
Based on the Global Shadow Banking Monitory Report 2015 issued by the Financial Stability Board, global shadow banking activities manage $80 \%$ of global GDP and $90 \%$ of the global financial system assets. Hence, this study aimed to examine the regulation and supervision of shadow banking activities in Indonesia. The method used is normative juridical with descriptive analytical research specifications. Based on the research results as follows : regulation of shadow banking in Indonesia's financial services sector covers all financial institutions outside the banking sector or Non-Bank Financial Institutions that the regulations are scattered in various rules. Indonesia has developed an integrated surveillance system for the entire financial services sector, include NBFIs. Development of shadow banking regulation will be based on the strengthening of reporting, monitoring, supervision and regulation.
\end{abstract}

Keywords : regulatory developments, shadow banking, and supervision

\section{Introduction}

\subsection{Background}

Recent years, shadow banking activity became one of the topics in the meeting of global financial services authority. The term shadow banking began to be used after the emergence of the financial crisis. The emergence of the term reflected a recognition of the increased importance of entities and activities 
structured outside of regular banking system that perform bank-like function. ${ }^{65}$ One of the cases related to shadow banking is a need to strengthen the regulation and oversight of shadow banking activity which is considered a good impact on the national financial system, regional and global. Citing the definition used by Financial Stability Board (FSB), ${ }^{66}$ shadow banking is defined as "credit intermediation involving entities and activities (fully or partly) outside the regular banking system" ${ }^{67}$, or non-bank credit intermediation in short. ${ }^{68}$ In recent years the most inportant such activities took the form of rapidly of expanding provisions of short term safe debt to financial intermediaries through money market funds and other sources outside of the regulated banking sector. ${ }^{69}$ As a financial intermediary, shadow banking plays an important role in market-based financial system, especially at the time of monetary crisis recovery. Similarly banking, shadow banking activities include maturity, liquidity, and credit transformation. In addition to the weakness of supervision and regulation, shadow banking not explicitly, to have access to sources ofliquidity such as the Central Bank or LPS. ${ }^{70}$ This is in contrast with the banking regulations that require attention prundential banking banking activities and obligations implementing the principle of good corporate governance. Law No: 10 Year 1998 aboutexchange law No: 7 Year 1992 about Banking prudential banking regulate this principle in 3 paragraph there is paragraph 2,8 , and 29 , and classification of the violation of this principle as a criminal offense.

\footnotetext{
* lastuti.abubakar@unpad.ac.id

65 Financial Stability Board, 2011, Shadow Banking; Scoping the Issues; A Background note of the financial Stability Board, April p. 2

${ }^{66}$ Financial Stability Board (FSB) is an organization of financial and supervisory authorities from major economies and international financial institutions.

67 FSB, 2015, Global Shadow Banking Monitory Report, p.1

68 FSB, 2015, Transforming shadow banking into resilient market based financing; an overview of progress and a road map for.P.1

${ }^{69}$ Gennaioli N, Shleifer A and VishnyR. W, 2013, A model of Sahdow Banking, The journal of finance, Vol. LXVIII No. 4 August, P. 1331

70 Zoltan Poszar, Tobias Adrian, Adam Ashcraft, Hailey Boeky, Shadow Banking, FRBNY Economic Policy Review, December 2013, p.1
} 
The growth of shadow banking is due to technological innovation and regulatory changes in the past several decades. For instance, traditional banks are under pressure to exit the regulated sector and rely on money market funds, securitisation and repo (repurchase agreements) for more profit. $^{71}$ In the shadow banking system, financing is mostly done through securitization techniques and financing guaranteed (secured funding) include assets backed commercial paper (CP), Assets backed securities, collateralized debt obligations (CDOs), and repo, that lack of transparency and weak oversight. One of the countries that have rapid growth is China's shadow banking.

The growth of shadow banking in China due to banking regulations are very strict so that the shadow banking practice grows at high interest. Policies issued by the People's Bank of China and China Banking Regulatory through joint decision in 2008 formally recognize and legalize the microfinance sector. Consequently since 2008, more than 5000 microfinance institutions have been issued licenses by the local government. ${ }^{72}$ The existence of micro-finance institutions have become an interesting alternative for people in china because of bank regulation are considered inflexible for micro businesses because of the many requirements such as collateral, loan ceiling and administrative requirements, while the culture of society is "keep away from problems or difficulties". Impact tightening banking regulations have made the lives of micro enterprises and agribusiness becomes difficult. The presence of shadow banking entities become the top choice for small business and agribusiness, while the shadow banking entities micro business loan is very favorable, because in addition to safe, better profits especially when dealing with the same customers, because for small business rate of interest is not an issue.

Shadow banking in china develop without adequate regulation, in practice, the more financial instruments that are engineered in their activities. On its way, activities undertaken shadow banks actually considered potential crises such as the

71 Shen Wei, Shadow banking System in China; Origin Uniqueness and Governmental Responses, Journal of International Banking Law and Regulation, Issue 1 (2013), P. 1

72 Joe Zhang, Inside China's Shadow Banking: The Next Subprime Crisis?, Enrich Professional Publishing, 2014, Hongkong, hlm. 7. 
financial crisis that hit the United States as a result of the sub-prime mortgage. Consequently, level of debt caused by the increasing practice of shadow banking.

In china cabinet held a series of strong regulation to regulate the shadow banking sector in an effort to impede debt increasing and This function returns the financial intermediation in the banking. Guidelines named "document No 107" aims to reduce the proliferation sector which in recent years was recognized as a key pillar of the financial system in china. ${ }^{73}$. China's State Council signaled against the challenges of non-bank institutions with increasing debt, and encourages nonbank institutions is back on his role as an asset manager and stop the credit business. In China, now trust company is a non-bank institution with all the assets under management.These guidelines are expected with the approval of authorities in China will be hoping that the restrictions on the funding of the shadow banking would prevent the parties from the exploitation of legal loopholes, and as a consequence the growth in debt levels will be low.

Problems of transparency and supervision of shadow banking is the cause why it lifted the agenda in international forums. In the FSB report to the G20 Finance Ministers and Central Bank Governors, entitled Financial ReformsProgress and Challenges, one of the elements agreed in the G20 Leaders meeting in St Peterburg include the shadow banking transformation into a market-based financing is transparent and robust ((transparent and resilient market based financing). ${ }^{74}$ Financial sector policy to address the risk of shadow banking is still passed at a meeting of the G-20 Finance Ministers and Governor of Central Bank (G20 MGM) on 22-23 February 2014 in Sydney. Indonesia as a participant, certainly expected to implement the agreements that have been made, particularly in policy making and oversight of shadow banking activities in Indonesia.

More than six years after the beginning of the subprime mortgage credit in the united states, many banks and banking system are still either ailing or slowly

73 World Finance, China Proposes new shadow banking regulations, Monday, January $6^{\text {th }}, 2014$.

74 Mark Carney- Financial Stability Board, Financial Reforms- Progress and Challenges, 17 Februari 2014. 
recovering. Dozens of large banks failed at the height of the crisis, mostly in the united states and in Europe. Surviving Banks had to merge or, in some cases radically change strategies, although sceptics might point out that the perilous practices widely Assumed to be at the root of the crisis (massive securitization, increased reliance of retail banks on wholesale funnds, single-minded pursuit of higher yields, high bonus) are now back infavour in the industry. At the same time, governments have had to step back into bankings after years of apparent lack of interest. In particular, in 2008 during the acute phase of the banking crisis, many government across the world had to rescue individual banks or, some cases, finance an amergency bailout programme. ${ }^{75}$

Under the conditions as described then that becomes one of the main issues that was agreed in the meeting of the Deputy Governor of the Central Bank and the Deputy Minister of Finance of the G-20 in Paris, France in 2011 adalan the issue of reform of the monetary system that impact on the regulation of the financial sector in Indonesia. In connection with the issue of financial sector reforms, the discussion focused on two critical issues that became the source of a new crisis passed, there are systematically important financial institutions (Global-SIFIs) dan shadow banking. First, efforts to improve the supervision and regulation of Global SIFIs be done by applying the provisions of loss-abosorbency capital in addition to the existing minimum capital to absorb losses that occur. Second, shadow banking activities (banking activities byinstitutions that are not Bank) which has been relatively unregulated and supervised as banking activities in general, strived for improved regulation and supervision.$^{76}$ Furthermore, in the same forum that the G20 meeting of Finance Ministers and Central Bank Governors (G-20 MGM) in Sidney Australia, G-20 looked still challenges that must continue to be managed in order to support global economic growth. Therefore, the G20 agreed to draw up a comprehensive growth strategy (comprehensif growth strategies). One of them is

75 Olivier Butzbach \& Kurt von Mettenheim, Alternative Banking and Financial Crisis, Pickering \& Chatto, 2014, hlm. 1.

76 Biro Humas, Bank Indonesia, Siaran Pers "Pertemuan deputi Kementerian Keuangan dan Bank Sentral G-20, 13 Juli 2011, diunduh dari www.bi.go.id,tanggal 10 Juni 2016. 
the commitment of the G20 will continue reforms to improve the resilience of financial institutions to crisis, address the systemic risk caused by the failure of large financial institutions, address the risk of shadow banking and financial market reform agenda continue derivatives. ${ }^{77}$ Thus, it can be concluded that the shadow banking activity in the next few years is still regarded as one of the causes of the global financial crisis which is still an important issue in the financial sector, in particular still require supervision and regulation better.

Based on the global shadow banking monitory 2015 report published by the Financial Stabilitiy Board, Indonesia is among countries that use the term shadow banking as a Non-Bank Financial Institusions (NBFIs). Regulation of the financial services sector in Indonesia, does not explicitly regulate the financial institutions which are grouped in the definition of shadow banking, but the key characteristics of shadow banking as conceived by regulators are credit intermediation in the capital markets, maturity transformastion, leverage and susceptibility to runs. The principal shadow banking activities and entities identified by regulator include the following:

a. Securitization vehicles such as asset backed commercial paper conduits (ABCP) and structured investment vehicles (SIVs)

b. Securities lending

c. Repurchase agreements

d. Securities broker dealers

e. Investment funds, including exchange traded funds and hedge funds that provide credit or are leveraged

f. Finance companies, including auto finance companies and leasing companies

g. Providers of credit insurance and financial guarantees. ${ }^{78}$

Therefore, there are included in the scope of shadow banking is the entire financial institutions other than banks and capital markets, that is includes insurance, pension

77 Biro Humas Bank Indonesia, G-20 Pandang Perekonomian Global Semakin Membaik. www.bi.go.id

78 Fein, Melanie L., The Shadow Banking Charade (February 15, 2013). Available at SSRN: http://ssrn.com/abstract $=2218812$ or http://dx.doi.org/10.2139/ssrn.2218812 
fund, financial institutions, specialized financial services institutions such as Insurance Companies, specialized financial services institutions such as Insurance Companies, PT Sarana Multigriya Finansial (Persero), PT Pegadaian (Persero), Social Security Administrator, dan Microfinance Institutions. Shadow banking activities in Indonesia, regulated and supervised by the FSA in accordance with the authority given by paragraph 5 law No. 21 Year 2011 about FSA, that "FSA function organized system of integrated regulation and supervision of all activities in the financial services sector", given the shadow banking activity can also have an impact on the macro economy, Bank Indonesia as the monetary authority in determining the nature of macroprudential policy is related to shadow banking. Shadow banking practices in Indonesia continues to grow in line with technological developments. Financial Services Authority aware of the development of technology-based financial services(financial technology) so it was necessary to review the existing regulations and reforming regulation in the financial services sector. Basically shadow banking has positive side including the shadow banking Provides diversification for the financial system and shadow banking and resillience Also offers more investment options and efficient pricing for consumers and businesses.

\subsection{Research Questions}

Recently, shadow banking supervision conducted by the government through the OJK. Regulation and proper supervision is required, given on the one side of the shadow banking will have an impact on financial stability, but on the other hand is required as a banking partner. based on the above problems, identified several issues are a) How the existence of shadow banking as non-bank intermediation in the regulation of the financial services sector in Indonesia? b) how the concept of oversight of shadow banking activities in order to support the stability of the financial services sector in Indonesia?

\section{Research Methods}


This study is a descriptive analysis to make a systematic identification, factual, and accurate information on the facts. The method used is normative juridical, including through comparative law research and systematic study of law as well as the synchronization of legislation existing. The study used secondary data in the form of primary legal materials that legislation associated with this research.secondary legal materials are literature, research result, law journal, case law and jurisprudence, and the results of the latest symposiums with research material. Furthermore, these data were analyzed qualitatively juridical.

\section{Result and Discussion}

\subsection{The Existence of Shadow Banking in the Regulation of the Financial System in Indonesia}

The existence of shadow banking in the regulation of the financial system in Indonesia can be found by searching in advance how the characteristics of the shadow banking, so the new can discover the existence of shadow banking are subject to a variety of different regulations. As for the characteristics of the shadow banking is: Has some bank like attributes; Using short term assets to find longer term lending (maturity transformation); mixed with all sort of new forms of money such as derivatives, off balance sheet vehicles (SPVs), securitisation, other debt instrument. NBFIs in Indonesia shows a graph of increase, but not significant when compared to growth of banking regulations are very strict. When viewed from the total assets, total assets of shadow banks INBFIs) is still below $10 \%$. 


\section{Figure 1 : Share of Total Financial Assets}

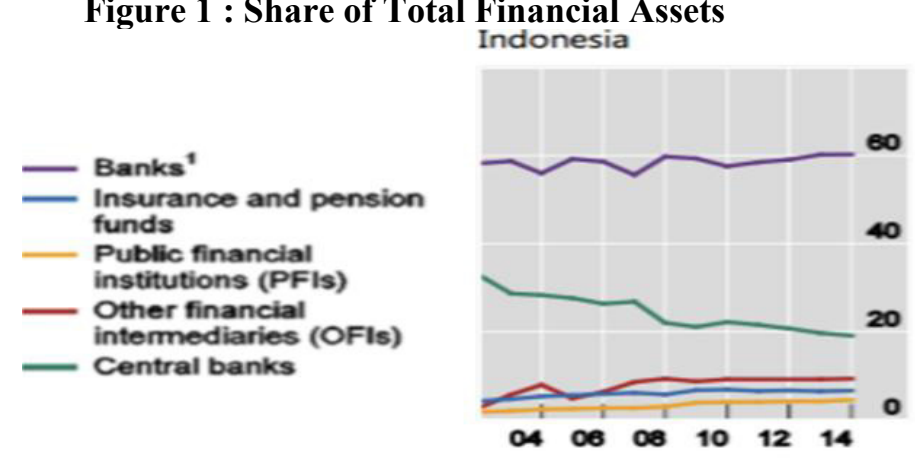

Source : FSB Global Shadow Banking Monitoring Report 2015

Furthermore, the growth of shadow banking in Indonesia globally also not significant when compared with other countries, especially Asian countries such as Hong Kong (less than 10\% GDP).

\section{Figure 2 : Growth of Shadow Banking in Various Country}

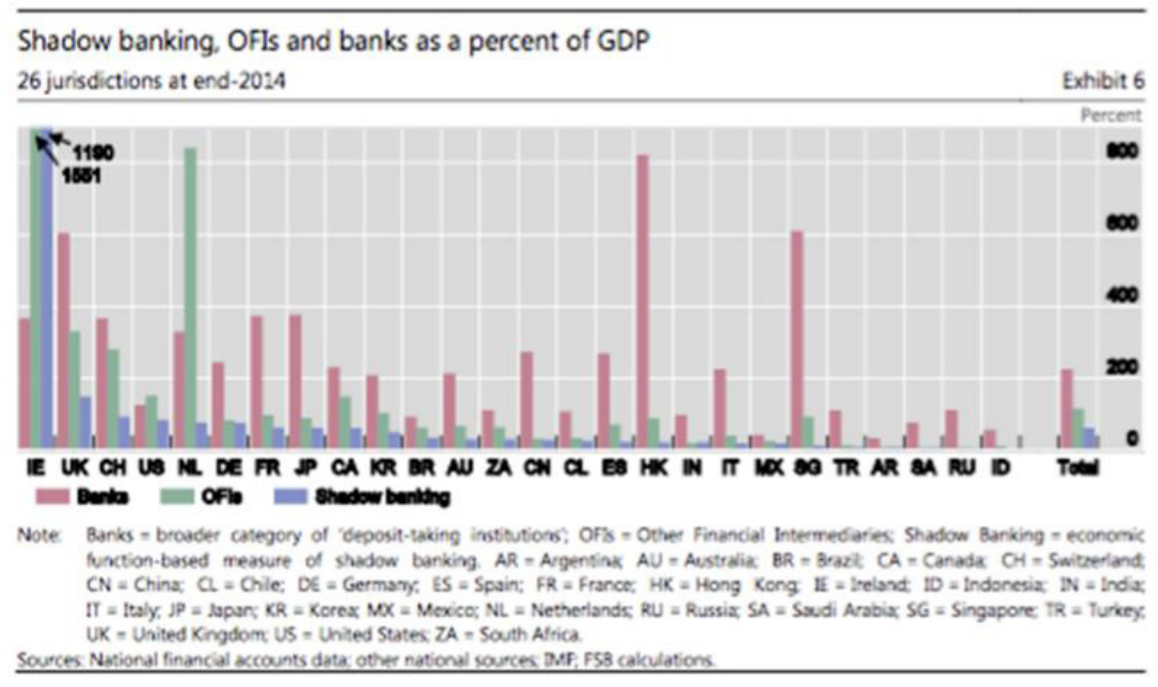

\subsection{Regulation of Shadow Banking Partial Indonesia}

In contrast to the banking and capital markets have been regulated in a special law with very strict regulations and detailed, non-bank financial institutions 
(NBFIs) are arranged in multiple rules in the form of laws or rules under law. In addition to the basic rules, NBFIs heavily regulated in FSA, ruling issued by the Financial Services Authority (FSA). The following regulations governing financial services institutions based paragraph 1 No. 7,8,9,10 Law No: 21 Year 2011.

Table 1. Regulation for Non Bank Financial Institutions

\begin{tabular}{|l|l|l|}
\hline No. & NBFIs & Regulation \\
\hline 1. & Insurances & Law No. 40/2014 \\
\hline 2. & Pension Funds & Law No.11/1992 \\
\hline 3. & Financing Institutions & $\begin{array}{l}\text { President } \\
\text { No.9/2009 }\end{array}$ \\
\hline 4. & Pawn Institutions & $\begin{array}{l}\text { Government Regulation } \\
\text { No. 51/2011 }\end{array}$ \\
\hline 5. & $\begin{array}{l}\text { Deposit Insurance } \\
\text { Institutions }\end{array}$ & $\begin{array}{l}\text { Law No.1/2016 } \\
\text { Financing Institutions }\end{array}$ \\
\hline 6. & $\begin{array}{l}\text { Housing Secondary } \\
\text { Financing Companies }\end{array}$ & $\begin{array}{l}\text { President Decree No. } \\
1 / 2008 \quad \text { and President } \\
\text { Decree No. 19/2005 }\end{array}$ \\
\hline 8. & $\begin{array}{l}\text { Social Security Agency } \\
\text { Law No.24/2011 }\end{array}$ \\
\hline 9. & $\begin{array}{l}\text { Micro Finance } \\
\text { Institutions } \quad \text { Law No.1/2013 }\end{array}$ \\
\hline
\end{tabular}

Source : processed by Tim

In practice, there is still a business entity or a financial services institution is also conducting intermediary, that regulation is not subject to FSA regulation as cooperatives, or not regulated. In line with the development of financial technology, the potential scope and regulation of shadow banking will continue to grow. Partial regulation is in line with the policy of the establishment of laws and regulations in Indonesia which adopts a partial codification. 


\subsection{Supervision of Shadow Banking as Non-Bank Intermediation by FSA}

Since the entry into force Law No. 21 year 2011, FSA organized system of regulation and supervision of integrated. Thus, the entire financial services sector, including NBFIs under the supervision of the FSA. This integrated model of supervision deemed appropriate to prevent or overcome the crisis and stabilize the financial system in Indonesia. Integrated under FSA supervision is done to give attention to the protection and education for consumers, which has two main objectives: first is to increase the confidence of investors and consumers in each of the activities and business activities in the financial services sector. Second, provide opportunities and opportunities for the development of the financial services sector in a fair, efficient, and transparent. In the long term, the financial industry will have positive benefits to stimulate increased efficiency in response to the demand of service. ${ }^{79}$ Therefore, it can be concluded that the regulation of the financial services sector in Indonesia has been arranged in a spread of the NBFIs and supervise its activities in an integrated manner. The problems that arise in practice Indonesia is sprung financial entities, especially those offering intermediary services through electronic media. The increased activity of technology-based shadow banking (financial technology) it is not yet covered by the regulation and supervision of the FSA, but the FSA already wary of this activity by requiring its players to sign up and get operational license from the FSA.

\subsection{The Concept of Regulation and Supervision of Shadow Banking as Non- Bank Intermediation}

Regulation of shadow banking is necessary as it touches upon both public interest and systemic risk of the financial industry. In Indonesia besides the FSA, Bank Indonesia as the banking authorities to give attention to shadow banking activities, given the shadow banking activity in practice brings potential threats to the stability of a country's monetary. In the context of macroprudential, holder of authority to make policy is Bank Indonesia as the Central Bank, which aims to

${ }^{79}$ Otoritas Jasa Keuangan, Buku Saku Otoritas Jasa Keuangan, Edisi Ke 2, Jakarta, 2015, hlm. 54 
prevent and reduce systemic risk; encourage a balanced intermediary function and quality as well as improving the efficiency of the financial system and access to finance. ${ }^{80}$ There are some basic things that need to be considered in determining macroprudential policies related to shadow banking include: higher capital requirement in a shorter timeline, shorter stance in applying Basel III, and Using interest rates as amajor monetary instruments to monitor the economic growth.

Regulation by the central bank needs through macroprudential policy has been a concern of the FSB who explained that if the unregulated shadow banking activity and properly supervised, could threaten monetary stability both at national level and will have an impact on the global economy. Therefore, regulation and supervision ofshadow banking activities will involve the two authorities, the FSA and the Bank Indonesia. To overcome the weakness of supervision and regulation of shadow banking, policy setting is more emphasis on the use of some elements, there is: 1) strengthening the reporting of NBFIs which includes among others: terms of what must be reported; time reporting, reporting coverage and a company profile; 2) strengthening monitoring to assess whether there are measurable changes or not, how it impacts the activity of NBFIs and coherence of the Bank as well as the risks that may arise so as to do a risk mitigation; and 3) strengthening integrated supervision to determine the extent of the relationship with the bank NBFIs. Strengthening the supervision over emphasize their enforcement and recommendation. And the last is 4) strengthening regulations through the implementation of governance and NBFIs should be treated like a bank. Regulation relating to NBFIs will continue to be developed considering the current growing technology-based financial activity (financial technology).

\section{Conclusion}

The existence of shadow banking in the regulation of the financial services sector in Indonesia concluded covers all non-bank financial institutions with the following characteristics: Has some bank like attributes; Using short term assets to

80 Departemen Kebijakan Makroprudensial, Optimalisasi Kebijakan Makroprudensial Untuk Mendukung Stabilitas Sistem Keuangan, Bank Indonesia, 2016. 
find longer term lending (maturity transformation); mixed with all sort of new forms of money such as derivatives, off balance sheet vehicles (SPVs), securitisation, other debt instrument that debt instrument that regulation scattered in several laws. The monitoring is integrated by the OJK. Bank Indonesia as the central bank has an interest to publish a wide range of policies related to shadow banking activities from makroprundensial aspects to ensure a stable financial system, balanced, and qualified.

The development and growth of shadow banking in Indonesia is still not significant when compared with the growth of assets under management and banking so that the impact on the national economy need not be feared. As a preventive effort by referring to the experience of countries such as China then shadow banking activities in Indonesia needs to be regulated either through strengthening reporting, monitoring, supervision and regulation that is integrated. Macroprudential policy regarding duty to maintain monetary stability in the future when it will regulate the shadow banking activities there are some things that concern among others: higher capital requirement in a shorter timeline, shorter stance in applying Basel III, and using interest rates as amajor monetary instruments to monitor the economic growth.

\section{References}

Bank Indonesia, Macroprudential Policy Departement. (2016). Optimizing macroprudential policy to Support the Financial Stability.

Communication Department, Bank Indonesia. (2016). Press Release "Financial Deputy Ministry And The Governor of Central Banks Meeting G-20, 13 Juli 2011. Retrieved from: www.bi.go.id

www.bi.go.id

, G-20 Glance Global Economy Improves. Retrieved from:

Fein, Melanie L. The Shadow Banking Charade (February 15, 2013). Available at SSRN: http://ssrn.com/abstract $=2218812$ http://dx.doi.org/10.2139/ssrn.2218812

Financial Services Authority. (2015). Pocket Book FSA, $2^{\text {nd }}$ Edition. Jakarta. Retrieved from: www.ojk.go.id 
Financial Stability Board. (2011). Shadow Banking; Scoping the Issues; A Background note of the financial Stability Board. Retrieved from: www.fsb.org

from: www.fsb.org

. (2015). Global Shadow Banking Monitory Report. Retrieved . (2015). Transforming Shadow Banking Into Resilient Market Based Financing; an Overview of Progress and a Road Map. Retrieved from: www.fsb.org

Gennaioli N, Shleifer A and Vishny R. W. (2013). A Model of Shadow Banking. The journal of finance, Vol. LXVIII.

Joe Zhang. (2014). Inside China's Shadow Banking: The Next Subprime Crisis?. Hongkong : Enrich Professional Publishing.

Mark Carney. (2014). Financial Stability Board, Financial Reforms- Progress and Challenges.

Olivier Butzbach \& Kurt von Mettenheim. (2014). Alternative Banking and Financial Crisis. Pickering \& Chatto.

Shen Wei. (2013). Shadow Banking System in China; Origin Uniqueness and Governmental Responses. Journal of International Banking Law and Regulation, Issue 1.

World Finance. (2014). China Proposes new shadow banking regulations.

Zoltan Poszar, Tobias Adrian, Adam Ashcraft, Hailey Boeky. (2013). Shadow Banking, FRBNY Economic Policy Review. 